\title{
Inhalation Valve Device
}

National Cancer Institute

\section{Source}

National Cancer Institute. Inhalation Valve Device. NCI Thesaurus. Code C50250.

A valve designed to regulate the flow of gases into a respirator or respiration system. 